\title{
Phenotyping And Genotyping Identification Of Important Human, Animal And Soil Of Dermatophytes
}

\author{
Taha $\mathrm{M}^{1}$, Essa $\mathrm{SI}^{2}$ and Younes $\mathrm{AI}^{3}$ \\ Faculty of Veterinary Medicine, Zagazig University ${ }^{1,3}$ \\ and Animal Health Research Institute ${ }^{2}$
}

\section{ABSTRACT}

In the current study, 62 dermatophyte isolates obtained from human and animal dermatophytosis as well as from soil were subjected for phenotypic and genotypic identification. The conventional (phenotypic) method for identification of dermatophytes in the present work was succeed to identify all isolates through macro-morphology, micro-morphology and differential media into species.

Identification of 48 isolates obtained from human cases revealed 15 M.canis, 12 T.violaceum, 12 T.rubrum, 5 E.fluccosum and 4 T.mentagrophytes. The eight isolates obtained from cattle were identified as T.verrucosum, while the four isolates obtained from dogs and cats were identified as M.canis. On the other hand, two dermatophyte isolates obtained from soil were identified as M.gypseum.

On other hand, three methods were used for molecular (genotypic) identification of dermatophytes which include: a) PCR for amplification of ITS1 and ITS4 followed by restriction fragment length polymorphism (RFLP) using MvaI for 30 isolates of dermatophyte formerly identified by phenotypic method. b)Application of PCR using single repetitive oligonucleatede (GACA)4 for30 dermatophyte isolates formerly identified by phenotypic and RFLP methods c) DNA sequencing which done for 5 representative isolates of M.canis, T.verrucosum, T.violaceum and T.rubrum.

While RFLP using Mval method and repetitive(GACA)4 method identified the thirty dermatophyte isolates into species identical to those identified by phenotypic methods, sequencing identified one isolate formerly identified by phenotypic,MvaI and(GACA) as T.rubrum with similarity $99 \%$ as T.raubitschekii.

Although molecular methods are rapid and represents technological advance in the laboratory diagnosis, it is expensive. So we recommended its use in absence of skilled mycologist, in identification of atypical or variants of dermatophyte species.

\section{INTRODUCTION}

Dermatophytes are the main cause of superficial mycoses. These fungi have the capacity to invade keratinized tissue of humans or animals to produce dermatophytosis (ringworm) that are generally restricted to the corneocytes of the skin, hair, and nail. Routine procedures for dermatophyte species identification rely on macroscopic examination of the colony (pigmentation of the surface and reverse sides, topography, texture, and rate of growth) and microscopic morphology (size and shape of macro conidia 
and microconidia, spirals, nodular organs, and pectinate branches) (1).

The etiologic agents of dermatophytosis are classified in three anamorphic (asexual or imperfect) genera, Epidermophyton, Microsporum and Trichophyton. The descriptions of the genera essentially follow the classification scheme of Emmons (2) on the bases of conidial morphology and formation of conidia and are updated following the discovery of new species (3).

Dermatophytes and their congeners have long been divided into anthropophilic, zoophilic and geophilic species on the basis of their primary habitat associations (4). Anthropophilic dermatophytes are primarily associated with humans and rarely infect other animals (5). Zoophilic dermatophytes usually infect animals or are associated with animals but occasionally infect humans. Geophilic dermatophytes are primarily associated with keratinous materials such as hair, feathers, hooves and horns after these materials have been dissociated from living animals and are in the process of decomposition (6).

Dermatophyte identification is usually depending on conventional methods based on detection of phenotypic characteristics such as microscopy and in vitro culture (7). Morphological and physiological characteristics can frequently vary, in fact, the phenotypic features can be easily influenced by outside factors such as temperature variation and medium (8).

In the last few years genotypic approaches have proven to be useful for solving taxonomic problems regarding dermatophytes. Genotypic differences are considered more stable and more precise than phenotypic characteristics (9). Molecular techniques are more beneficial for dermatophyte identification as they are rapid and more sensitive. Moreover, these methods rely on genetic makeup, which is more constant than phenotypic characterization, and they can identify atypical dermatophytes that could not be identified by culture based techniques. These genotypic approaches can identify dermatophytes into species as well as the strain levels $(10,11)$. Molecular methods, such as, PCR (random amplification of polymorphic DNA (RAPD) (7), arbitrarily primed PCR (AP-PCR) (12) and PCR finger printing (13) have brought important progress in distinguishing between species and strains (14).

The present work was done to study methods of identification of dermatophytes from human, animal and soil by conventional and genotypic methods.

\section{MATERIAL AND METHOD}

Samples

Human samples: Fifty five skin scrapings and hair were collected from patients suffering from dermatophytosis and attending to Out Patient Clinic of Dermatology at Misr University for Science and Technology (MUST) and private laboratory for mycology investigation (Cairo) between May 2010 to September 2011. The cases include 25 tinea capitis, 15 Tinea corporis, 10 Tinea cruris and 5 tinea pedis.

Ten skin scrapings and hair samples were collected from cattle showed clinical signs of ringworm at private farms in Zagazig Providence. Five skin scraping and hair samples were collected from 2 dogs and 3 cats showed ringworm at private veterinary clinic and owner's. Five soil samples contaminated by animal wastes were collected at El Sharkia Governorate from soil.

Collection of samples: after treated the lesions with $70 \%$ ethyl alcohol, skin scrapings were collected from each case in sterile Petridish $(6 \mathrm{~mm})$ by using new sterile blade scalpel for each case. Hairs were collected by forceps.

Direct microscopic examination was done after use of $\mathrm{KOH}$, DMSO, orcalcofluore 
white (Remel) which used for direct microscopic examination for fungal elements by light or fluorescent microscope.

Cultivation of the specimens

Skin scraping and hair fromhuman and animal samples were inoculated in the following media: Dermasel agar, DTM, DermDuet, and In-Try DM (All inoculated media were incubated at $30^{\circ} \mathrm{C}$ for two weeks.

\section{Hair-bait technique (19)}

Soil sample placed on Petri dish then covered by sterilized short hair $(3-5 \mathrm{~cm})$.Drops of mixture of cycloheximide and chloramphenicol were added then incubated at room temperature for 10-15 days. The growth transferred to Dermasel agar.

Identification of isolated dermatophyte

Phenotypic identification (20-24)

a) Macro-morphological examination: Growth rate, consistency, surface color, reverse color as well as change of DTM and in-Try DM color were examined every three days of inoculation until the end of incubation.

b) Micro-morphological examination: in case of In Try DM, the cartilage was examined through clear viewing window under microscope for hyphae and conidia, in case of other media particles from the growth were added on slide with drops of LPCB then overlaid by cover slip and examined under microscope for modification of hyphae, macroconidia and microconidia.

c) Cultivation on differential media: subculture of the isolated dermatophyte was done on the following media, BCP,LA, MHB and RG (21-24).

All inoculated media were examined for rate of growth,surface and reverse color of the growth and changes of the medium. Sporogenous effect of the media was examined by microscopic examination of the colonies after LPCB.
Genotypic identification of the isolates

Thirty isolate from 7 species of dermatophytes identified by phenotypic methods were subjected for PCR (Table 1).

Table 1. Samples subjected to PCR

\begin{tabular}{lcccc}
\hline Samplesource & Human & Animal & Soil Total \\
\hline T. verrucosum & - & 6 & - & 6 \\
M. canis & 4 & 3 & - & 7 \\
E. floccosum & 2 & - & - & 2 \\
T. rubrum & 4 & - & - & 4 \\
T. & 2 & - & - & 2 \\
mentagrophytes & & & & \\
T. violaceum & 7 & - & - & 7 \\
M. gypseum & - & - & 2 & 2 \\
Total & 19 & 9 & 2 & 30 \\
\hline
\end{tabular}

Kits for DNA extraction: DNA extraction from isolated sermatophytewas done using DNeasy plant Mini kit Qiagen Genomic Protocol extraction kit as described by manufacturer manual of Qiagen, Germany.

Primers: There are 2 types of primers were used

General primer (11)

Forward (ITS1) 5'-TCCGTAGGTGAACCTGCGG-3'.

Reverse (ITS4)5' TCCTCCGCTTATTGATATGC-3'.

Repitative primer (GACA) 4 (11)

5'-GACAGACAGACAGACA-3'

Gene Sequancing was done by Lab Technology Korea for 5 representative isolates $\{T$. violaceum (1), M. canis (1), T.verrucosum (1) and T. rubrum (2)\}. 


\section{RESULTS}

Direct microscopic examination

In human cases positive microscopic examination $(\mathrm{KOH})$ was detected in $92.72 \%$. Whilecattle ringworm cases revealed positive $\mathrm{KOH}$ in $100 \%$, $80 \%$ ringworm cases of dogs and cats were positive $\mathrm{KOH}$.

Isolation of dermatophytes from examined samples

a) Dermatophytes were isolated from 48 out of55 human cases on Dermasel agar and DTM, while In-Try DM and Derm-Deut failed to isolate many of them.

b) Dermatophytes were isolated from 8 out of 10 cases of cattle ringworm. c) Dermatophytes were isolated from 4 out of 5 dogs and cats, four isolates (one from dog and 3 from cats).

d) Dermatophytes were isolated from 2 out of 5 soil samples.

Table4 showed the results of cultivation on different media used for isolation of dermatophytes from human, animals and soil. Dermasel agar and DTM were suitable for isolation of human dermatophytes while InTry DM and Derm-Deut failed in isolation of some of them. Dermasel and DTM were the most suitable for isolation of dermatophytes from cattle. All media succeeded in isolation of dermatophyte from dogs and cats as well as from soil. Figs.(1 and 2) showing macro and micromprphology of $M$. canis on In Try DM.

\section{Table 2. Comparison between dermasel agar, DTM, In-Try DM and Derm-Deut in isolation of dermatophytes}

\begin{tabular}{lcccc}
\hline \multicolumn{1}{c}{ Media/ source } & Dermasel agar & DTM & In Try DM & Derm-Deut \\
\hline Human & 48 & 48 & 38 & 22 \\
Cattle & 8 & 8 & - & - \\
$\begin{array}{l}\text { Dogs and cats and cats and } \\
\text { cats }\end{array}$ & 4 & 4 & 4 & 4 \\
Soil & 2 & 2 & 2 & 2 \\
Total isolates & 62 & 62 & 44 & 28 \\
\hline
\end{tabular}

C- Phenotypic Identification of dermatophyte

Macro and micro-morphologicalidentification of dermatophytes isolates

With help of keys manual for identification of dermatophytes. Sixty and two isolates obtained fromhuman,animals and soil were identified according to macro-morphology and micro-morphology as the following : a) Human: As showed in table (3) 48 dermatophyte isolates were identified asM.canis (15), T.violaceum (12), T.rubrum (12), T.mentagrophytes (4) and E. Fluccosum (5). While M.canisand T.violaceumwere the causative agent of tinea capitis,T.rubrum,M.canis and T.violaeumwere the causative of tinea corporis. On the other hand T.cruris caused by E.fluccosum and T.rubrum, and tinea pedis caused by T.mentagrophytes. 
Table 3. Identified dermatophytes among 48 human samples

\begin{tabular}{lccccc}
\hline & M.canis & T.violaceum & T.rubrum & T.mentagrophytes & E.fluccosum \\
\hline Tinea capitis & 12 & 10 & - & - & - \\
Tinea corporis & 3 & 2 & 9 & - & 5 \\
Tinea cruris & - & - & 3 & 4 & - \\
Tinea pedis & - & - & - & 4 & 5 \\
Total & 15 & 12 & 12 & & \\
\hline
\end{tabular}

b) Cattle: The eight isolates of dermatophytes obtained from cattle dermatophytosis were identified according to macromorphology and micromorphology into T.verrucosum.

c) Dogs and cats: Four isolates obtained from dogs and cats were identified as M.canis

d) Soil: Two isolates obtained from soil samples identified as M.gypseum.

Figs. (3, 4, 5, 6 and 7) showing the micromorphology of $M$. canis, M.gypseum, T.mentagrophytes, $T$. rubrum and $T$. violaceum.
Cultivation on differential media

Cultivation of dermatophyte isolates on RG,LA,PCP and MHB media confirmed the identification of dermatophyte after macro and micro- morphological identification. Figs. (8, 9, 10 and 11) showing the growth of dermatophytes on BCB, RA and MHB. Increase pigmentation, change of medium colour, hydrolosis of casein as well as increase conidiation were the tool used in this type of identification. 


\section{M.Canis on In Try DM}

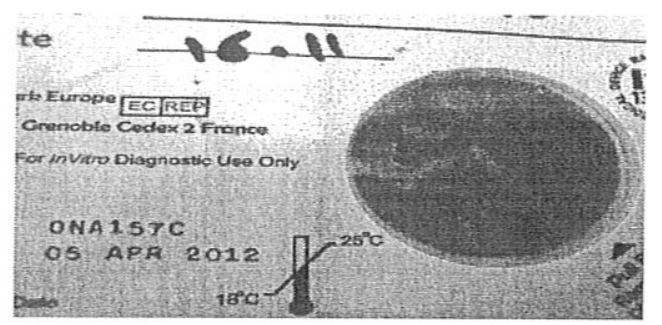

Fig. 1. M. canis on In Try DM hairy white colony and the medium turned red

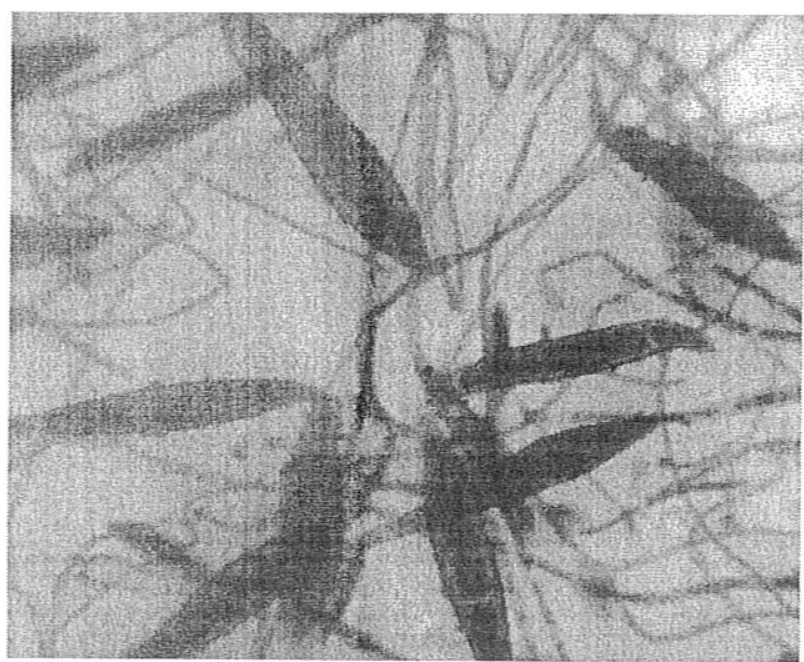

Fig. 3. M. canis showing macroconidia (LPCB)

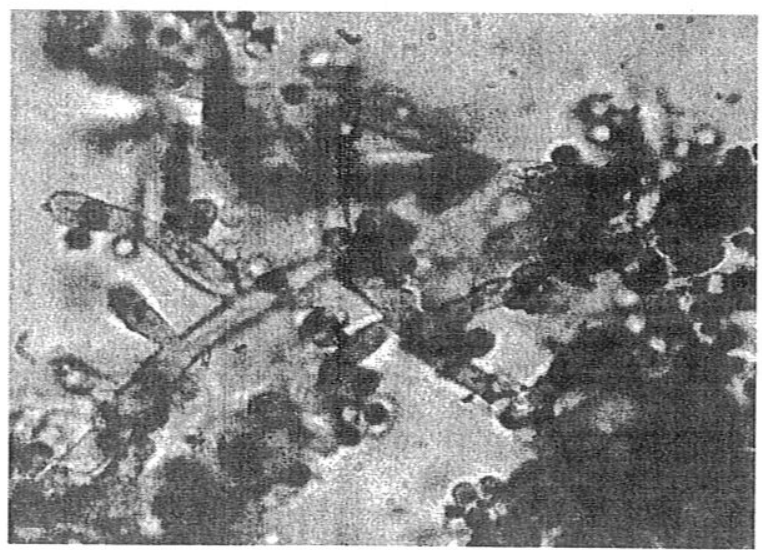

Fig. 5. Microscopic examination of $T$. mentagrophytes macroconidia and microconidia (LPCB)

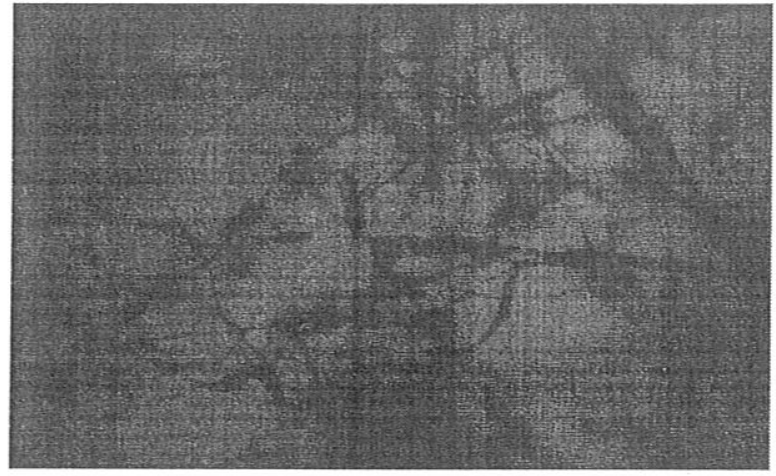

Fig. 2. Microscopic exam. of M. canis on In Try DM showing macroconidia

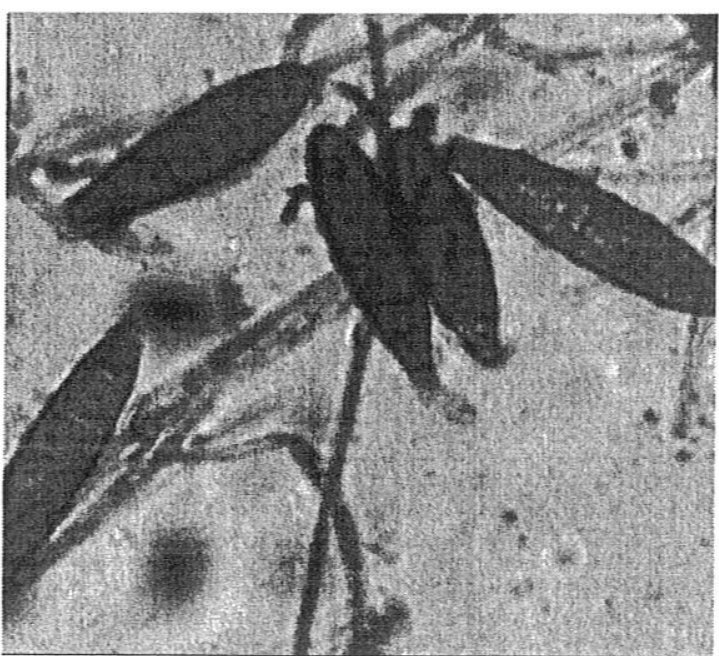

Fig. 4. Microscopic examination of $M$. gypseum showing spindle shaped macroconidia (LPCB)

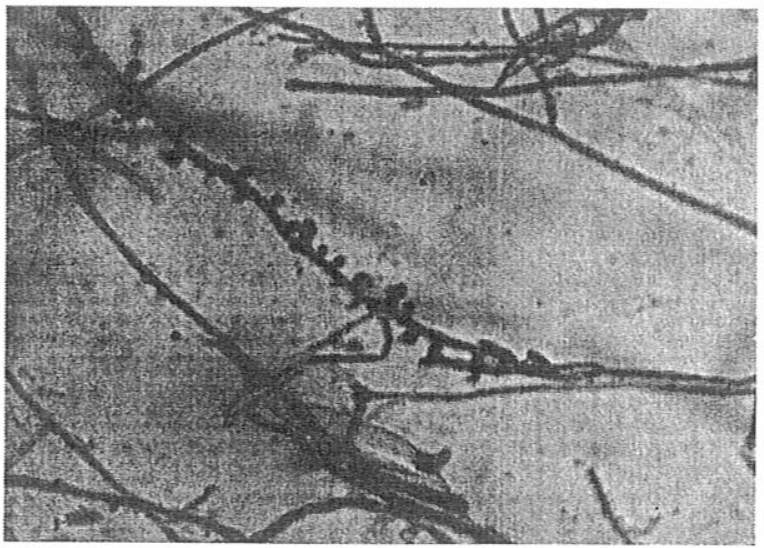

Fig. 6. Microscopic exam. of T. rubrum showing microconidia sessile on sides od hyphae (LPCB) 


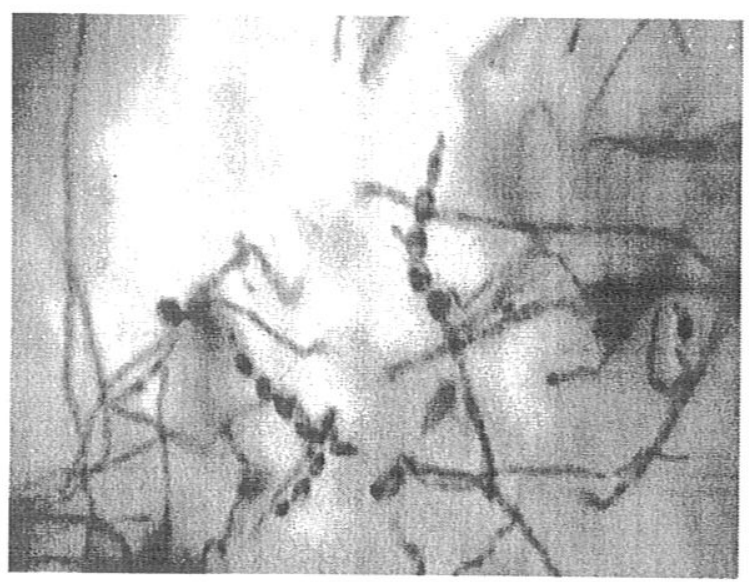

Fig. 7. Microscopic exam. of $T$. verrucosum showing chains of chlamydospores (LPCB)

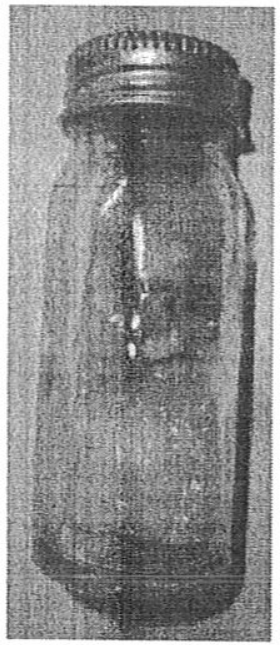

Fig. 9. M. canis on RG showing yellow pigmentation

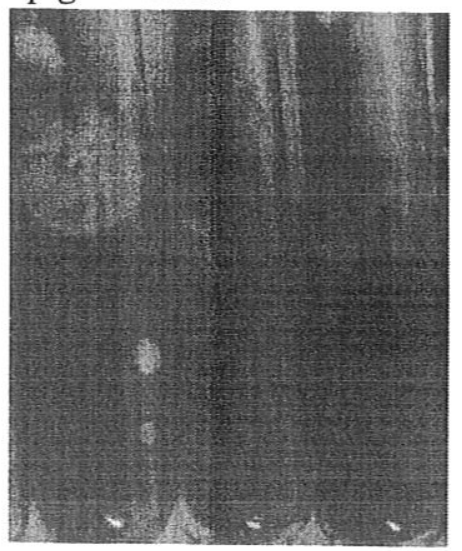

Fig. 11. T. verrucosum on MHB (14 d) showing good growth with coloration of the medium

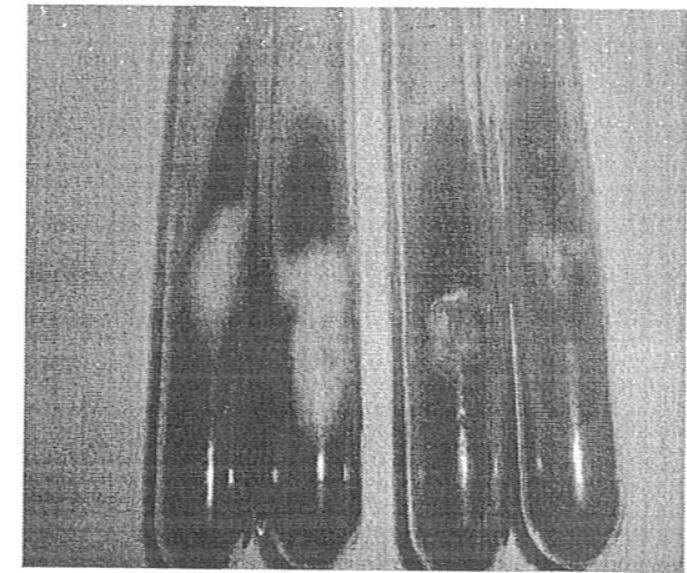

Fig. 8. BCP medium: left $T$. mentagrophytes turned the medium purple while right $M$. canis showing profuse growth without changing in color

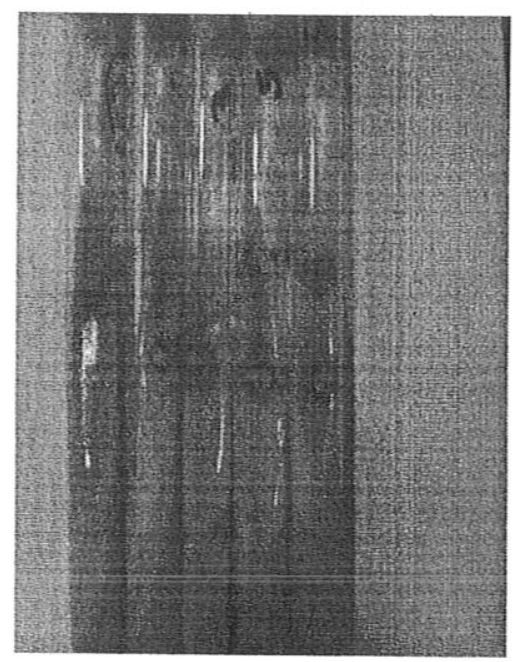

Fig 10. T. verrucosum on MHB with halo zone around colonies and green color (7 days). 


\section{D.PCR results}

In the present study three methods were used for molecular identification of dermatophytes which include:

a) PCR for amplification of ITS1 and ITS4 by common primer followed by restriction fragment lengthpolymorphism (RFLP) using Mval.

b) Application of PCR using single repetitive oligonucleatede (GACA)4

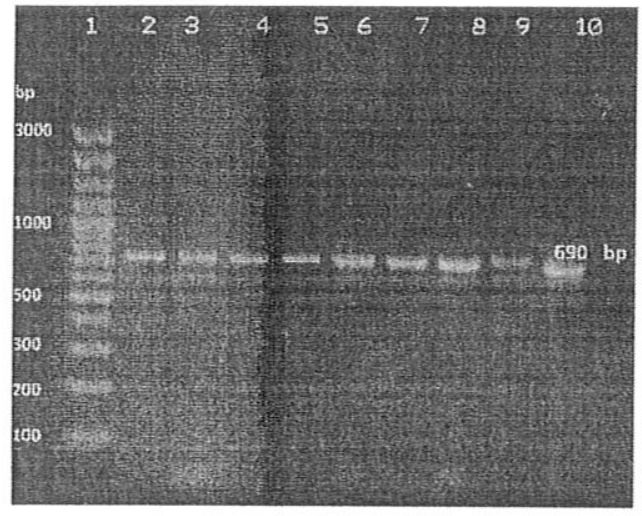

Fig. 12. Agarose gel electrophoresis T. verrucosum and Microsporum gypsum DNA products

Lane 1: Molecular weight marker,

Lane 2-7: T.verrucosum (cattle).

Lane 8-9: Microsporum gypsum (Soil)

Lane10: E. floccosum

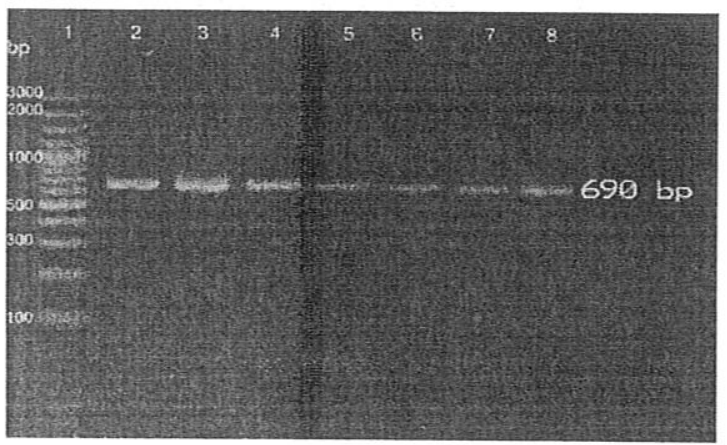

Fig. 14. Agarose gel electrophoresis for PCR product of the ITSI and ITSII of the $T$. violaceum Lane 1: Molecular weight marker, Lane 2-8: T. violaceum strain (human) c) DNA sequencing which done only for 5 representative isolates.

Identification of dermatophye isolates by common primer and RAPD

PCR with the ITS1/ITS4 primer set for 30 dermatophyte isolate resulting in amplified products of approximately a fragment of 690 bp specific for $T$. violaceum, T. rubrum, $T$. verrucosum, $M$. gypseum and $T$. iolaceum (Fig. 12,13 and 14 and 740 bp for M. canis (Fig .15).

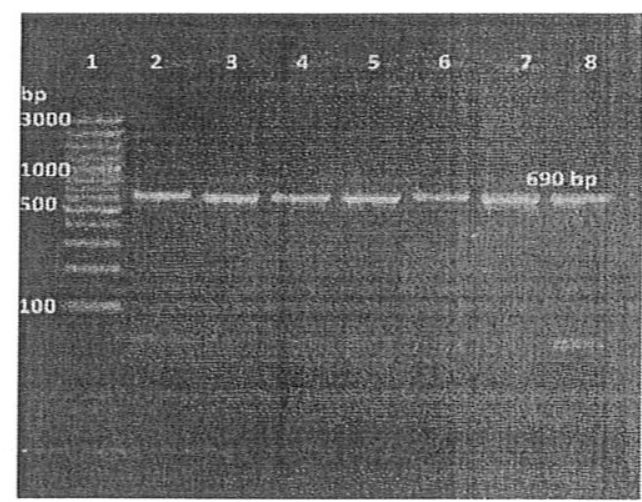

Fig. 13. Agarose gel electrophoresis T. rubrum and T. mentagrophyte DNA products Lane 1: Molecular weight marker, Lane 2-5:T. rubrum (human) Lane 6-7: T.mentagrophyte (human) Lane 8: E. floccosum (man

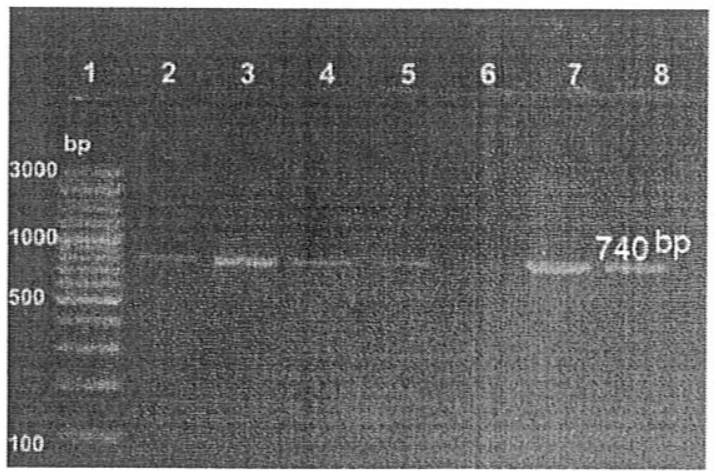

Fig. 15. Agarose gel electrophoresis $M$. canis DNA products

Lane 1: Molecular weight marker, Lane 2-8: $M$. canis (Human) 
Mval digestion of these amplified products from each of the dermatophyte isolates revealed unique restriction patterns, with no interspecies variation. $M$. canis isolates showed three band patterns, ranging from $100 \mathrm{bp}$ to $500 \mathrm{bp}$ in size, with a marked

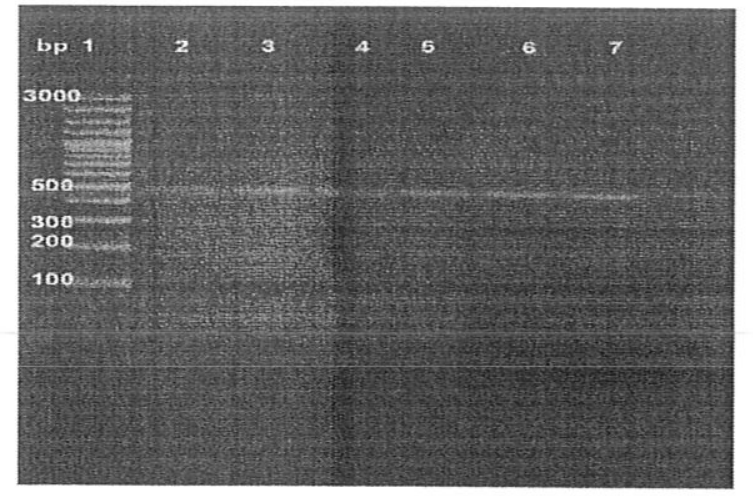

Fig. 16. Agarose gel electrophoresis of MvaI restriction products of $M$. canis

Lane 1: Molecular weight marker,

Lane 2-7: M. canis (Human)

Mval restriction products of sizes ranging between 100 bp and $500 \mathrm{bp}$ T.verrucosum, M.gypseum, T.mentagrophytes (Fig.18).

and E.flucosum showed fourband patterns its size difference between the largest and middle bands(Fig.16).

On the other hand, both $T$. violaceum and T. rubrum isolates resulted in four bands, with sizes ranging between 50 bp and 400 bp (Fig. 17).

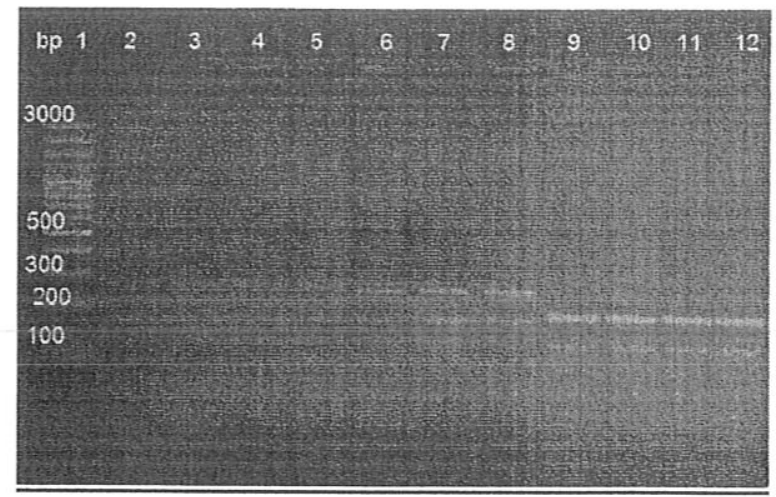

Fig. 17. Agarose gel electrophoresis of MvaI restriction products of $T$. violaceum and $T$. rubrum

Lane 1: Molecular weight marker, Lane 2-8: T. violaceum

Lane 9-12: T. rubrum

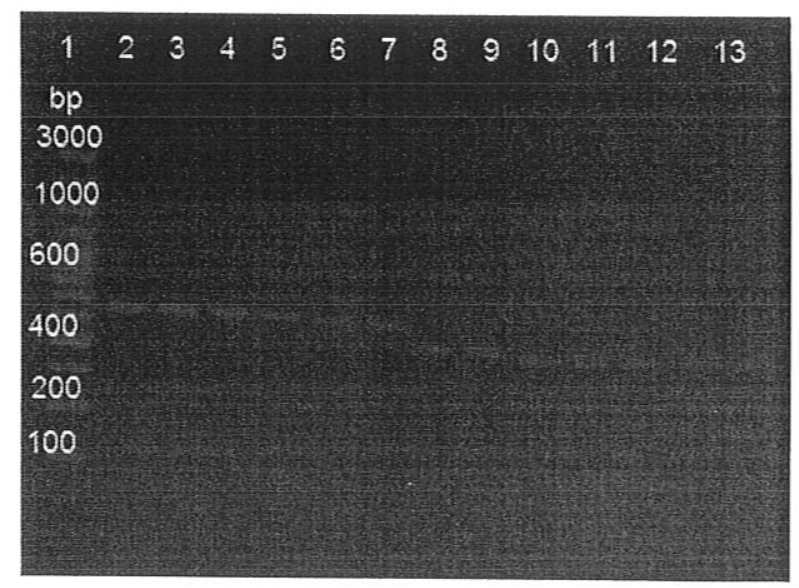

Fig. 18. Agarose gel electrophoresis of MvaI restriction products of T.verrucosum, M. gypsum, T. mentagrophyte,.floccosum 
(a) Identification of dermatophyte by (GACA) 4 based PCR

Thirty dermatophyte isolates were amplified with (GACA)4. The results showed that the numbers of PCR bands ranged from 9 to 13 (size range, $200 \mathrm{bp}$ to $1300 \mathrm{bp}$ ).

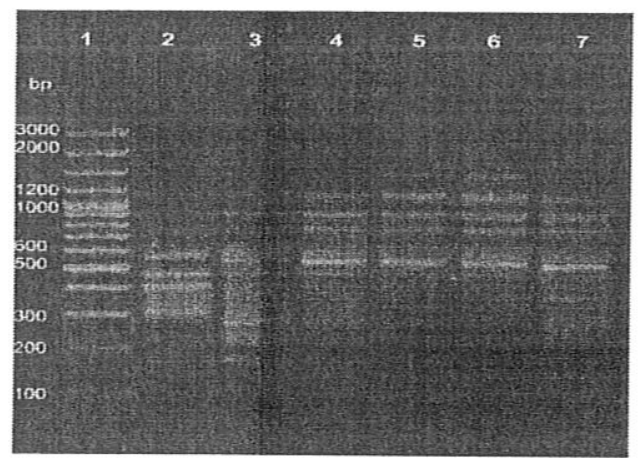

Fig. 19. Agarose gel electrophoresis DNA products Lane 1: Molecular weight marker, Lane 2-6: T. verrucosum (cattle) Lane 7: T. verrucosum (Human)

Profiles for $M$. gypsum, and T. rubrum were more complex, in $M$. gypsum comprising eleven or twelve bands, between $160 \mathrm{bp}$ and approximately 1,200 bp in size. In $T$. rubrum we found five to twelve bands ranged from 200 to 2000 bp.(Fig.21).

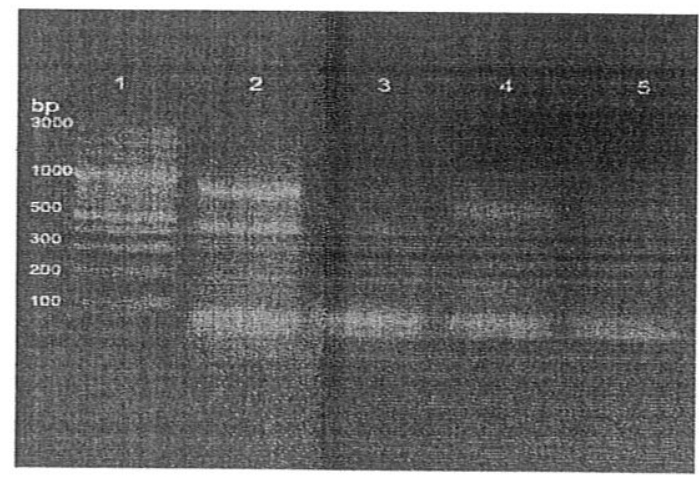

Fig. 21. Agarose gel electrophoresis of DNA products of Dermatophytes isolates Lane1: Molecular weight marker, Lane 2-3: E. floccosum, Lane 4-5: T. mentagrophytes
T. verrucosum(6 isolates)revealed banding patterns ranging from $177 \mathrm{bp}$ to $1,240 \mathrm{bp}$ in size, with one strong band of 628 bp.(Fig.19).

(GACA)4-based PCR of $M$. canis strains revealed the most complex profiles, with up to 11 bands, ranging from $170 \mathrm{bp}$ to $1,200 \mathrm{bp}$ in size. There was no interspecies variation among $M$. canis isolates, all of which had the same band pattern (Fig. 20).

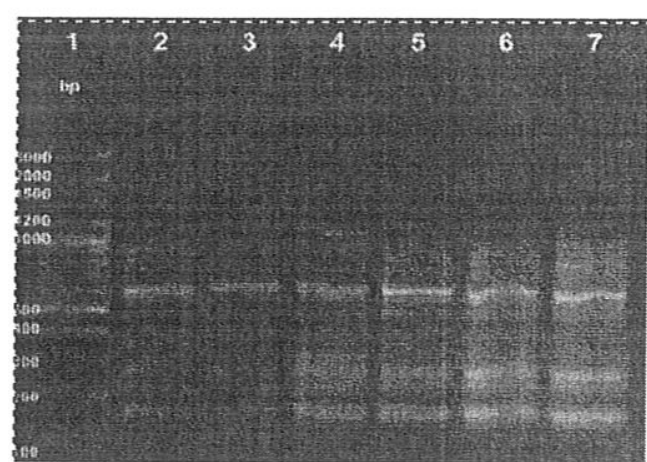

Fig. 20. Agarose gel electrophoresis DNA products using GACA primer

Lane1: DNA ladder, Lane 2-7: $M$. canis (Human)

\section{DNA sequencing}

While,M.canis, T.verrucosum, T. violaceum and one isolate of T.rubrum were found to be identical to similar in Gen Bank, the other isolate of T.rubrum obtained from a case of human tinea corporis was found to be identical (99 \%) for the sequence of theT.raubitscheki (Figs.14,15 and 16) and table (4). 
Table 4. Sequencing of five dermatophye isolates relate to 4 species

\begin{tabular}{|c|c|c|c|c|}
\hline S. N. & Description & $\begin{array}{l}\text { Max } \\
\text { score }\end{array}$ & $\begin{array}{l}\text { Total } \\
\text { score }\end{array}$ & $\begin{array}{l}\text { Max } \\
\text { ident }\end{array}$ \\
\hline $1 \mathrm{~F}$ & $\begin{array}{l}\text { Trichophyton violaceum isolate UOA/HCPF13250 } \\
18 \mathrm{~S} \text { ribosomal RNA gene, partial sequence; internal } \\
\text { transcribed spacer } 1,5.8 \mathrm{~S} \text { ribosomal RNA gene, and } \\
\text { internal transcribed spacer 2, complete sequence; and } \\
28 \mathrm{~S} \text { ribosomal RNA gene, partial sequence }\end{array}$ & 304 & 356 & $97 \%$ \\
\hline $1 \mathrm{R}$ & $\begin{array}{l}\text { Trichophytonviolaceum isolate UOA/HCPF } 1325018 \mathrm{~S} \\
\text { ribosomal RNA gene, partial sequence; internal } \\
\text { transcribed spacer 1, 5.8S ribosomal RNA gene, and } \\
\text { internal transcribed spacer 2, complete sequence; and } \\
\text { 28S ribosomal RNA gene, partial sequence }\end{array}$ & 304 & 401 & $94 \%$ \\
\hline $2 \mathrm{~F}$ & $\begin{array}{l}\text { Microsporumcanis strain ATCC MYA- } 4605 \text { 18S } \\
\text { ribosomal RNA gene, partial sequence; internal } \\
\text { transcribed spacer 1, 5.8S ribosomal RNA gene, and } \\
\text { internal transcribed spacer 2, complete sequence; and } \\
\text { 28S ribosomal RNA gene, partial sequence }\end{array}$ & 880 & 880 & $99 \%$ \\
\hline $2 \mathrm{R}$ & $\begin{array}{l}\text { Microsporumcanis strain ATCC MYA- } 4605 \text { 18S } \\
\text { ribosomal RNA gene, partial sequence; internal } \\
\text { transcribed spacer 1, 5.8S ribosomal RNA gene, and } \\
\text { internal transcribed spacer 2, complete sequence; and } \\
\text { 28S ribosomal RNA gene, partial sequence }\end{array}$ & 1227 & 1227 & $98 \%$ \\
\hline $3 \mathrm{~F}$ & $\begin{array}{l}\text { Trichophytonverrucosum 5.8 rRNA gene and ITS1 } \\
\text { and ITS2 DNA (strain CBS 134.66) }\end{array}$ & 1188 & 1188 & $99 \%$ \\
\hline $3 \mathrm{R}$ & $\begin{array}{l}\text { Trichophyton verrucosum } 5.8 \text { rRNA gene and ITS1 } \\
\text { and ITS2 DNA (strain CBS 134.66) }\end{array}$ & 1184 & 1187 & $99 \%$ \\
\hline $4 \mathrm{~F}$ & $\begin{array}{l}\text { Trichophyton rubrum 5.8 rRNA gene and ITS1 and } \\
\text { ITS2 DNA (strain CBS 392.58) }\end{array}$ & 1085 & 1488 & $96 \%$ \\
\hline $4 \mathrm{R}$ & $\begin{array}{l}\text { Trichophyton rubrum } 5.8 \text { rRNA gene and ITS1 and } \\
\text { ITS2 DNA (strain CBS } 392.58 \text { ) }\end{array}$ & 1184 & 1184 & $99 \%$ \\
\hline $5 \mathrm{~F}$ & $\begin{array}{l}\text { Trichophyton raubitschekii strain BMU04349 18S } \\
\text { ribosomal RNA gene, partial sequence; internal } \\
\text { transcribed spacer 1, 5.8S ribosomal RNA gene, and } \\
\text { internal transcribed spacer 2, complete sequence; and } \\
28 \mathrm{~S} \text { ribosomal RNA gene, partial sequence }\end{array}$ & 1134 & 1134 & $99 \%$ \\
\hline $5 \mathrm{R}$ & $\begin{array}{l}\text { Trichophyton raubitschekii strain BMU04349 } 18 \mathrm{~S} \\
\text { ribosomal RNA gene, partial sequence; internal } \\
\text { transcribed spacer 1, 5.8S ribosomal RNA gene, and } \\
\text { internal transcribed spacer 2, complete sequence; and } \\
28 \mathrm{~S} \text { ribosomal RNA gene, partial sequence }\end{array}$ & 1134 & 1134 & $99 \%$ \\
\hline
\end{tabular}

From the above mentioned results we become confident to the similarity of genotypic result and phenotypic result except in T.rubrumwhich has similarity in some morphological and physiological characters withT.raubitschekiiwhich considered homologue genetically with T.rubrum (Figs. 22\&23). 
Sequence ID: gb|EU921293.1|Length: 774Number of Matches: 1 Related Information

Range 1: 153 to 774 GenBankGraphics Next Match Previous Match Alignment statistics for match \#1

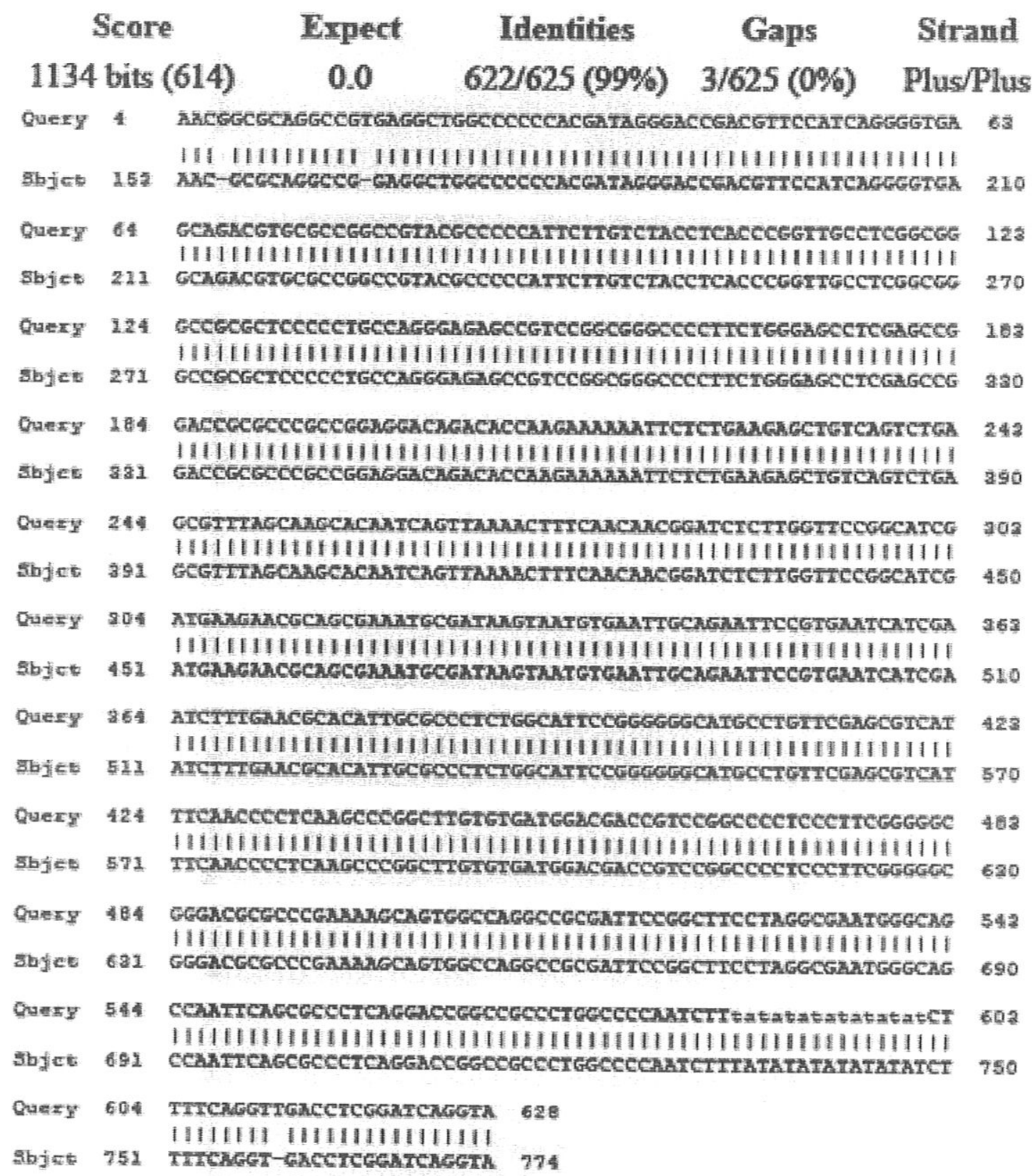

Fig. 22: Forward sequencing for sample number 5 . 
Sequence ID: gb|EU921293.1Length: 774Number of Matches: 1

Related Information

Range 1: 102 to 774 GenBankGraphics Next Match Previous Match Alignment statistics for match \#1

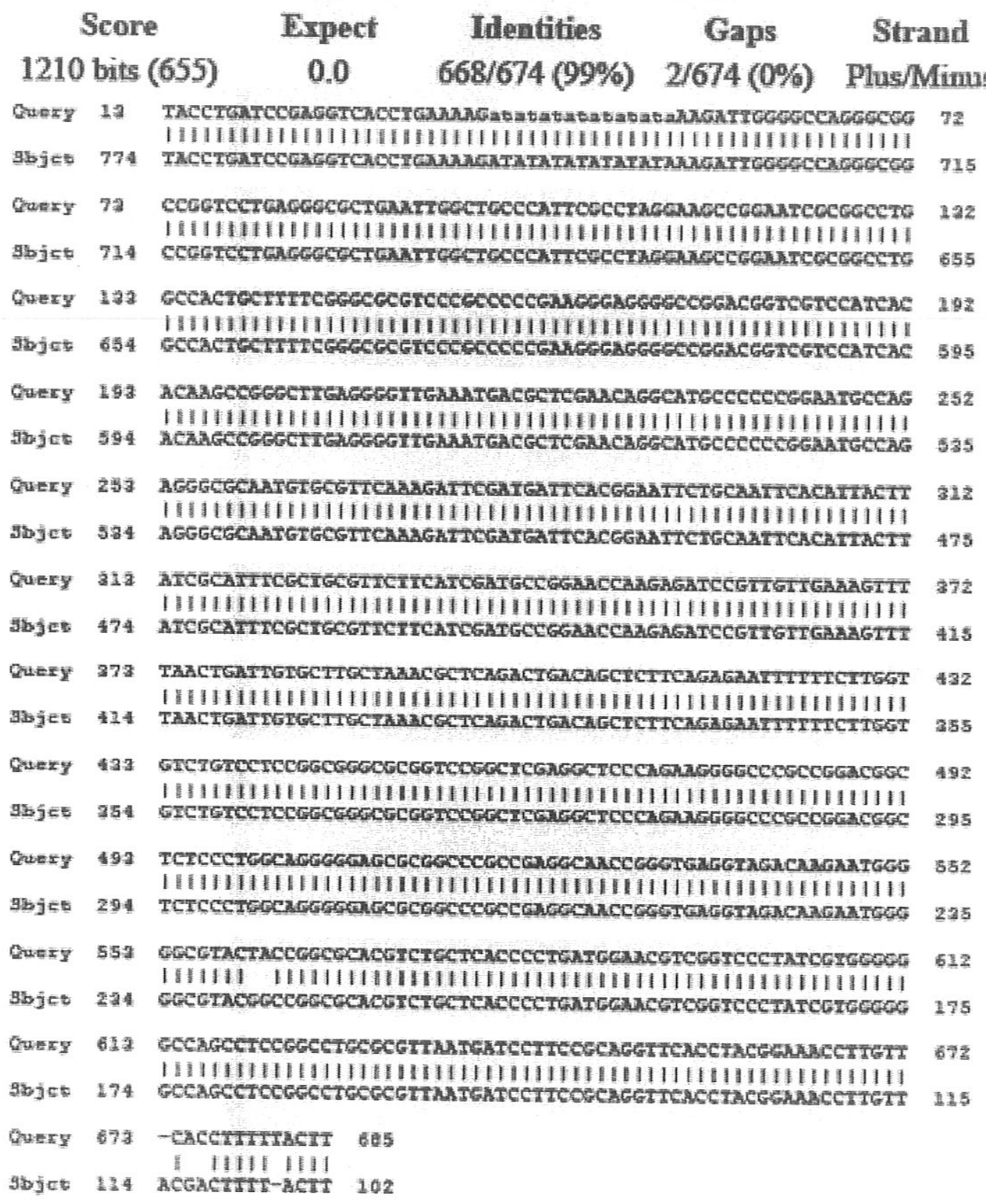

Fig. 23:Reverse sequencing for sample number 5. 


\section{DISCUSSION}

Conventional methods for dermatophytes identification are based on detection of fungal elements by direct microscopy of clinical specimens combined with culture-based identification including macro-morphological, micro-morphological and physiological characters of the colonies. In the last few years, genotypic approaches have been proven to be useful for solving identification problems regarding dermatophytes. Genotyping differences are considered more stable and more precise than phenotypic identification characteristics (2527).

The aim of the present study was done to correlate between conventional and molecular methods for dermatophyte isolates obtained from human, animals and soil.

Fifty five human samples and 15 animal samples (cattle, dogs and cats) collected from cases of dermatophytosis as well as 5 soil samples were subjected for mycological examination.

While human specimens gave positive direct microscopic examination (KOH) in $92.72 \%$ and positive culture in $87.27 \%$, animal specimens gave positive $\mathrm{KOH}$ in $93.33 \%$ and $80 \%$ positive culture. Similar results were reorded by previous authors (17, 28,29 ) who contributed the higher positivity of $\mathrm{KOH}$ than culture due to; the cases were under treatment, the culture contaminated by rapid growing fungi giving no chance for slowly growing dermatophytes to be appear or even the use of unsuitable media for certain dermatophyte with higher nutritional requirements. In general $\mathrm{KOH}$ and culture complete each other and while direct microscopic examination showed higher sensitivity, culture showed higher specificity as mentioned (30).

Comparison between four media namely; Dermasel agar, DTM, In-Try DM and Derm-Deut, it was found that Dermasel and DTM succeeded in isolation of 62 dermatophyte isolates from total of 75 specimens while from In-Try DM and Derm-
Deut 44 and 28 dermatophyte isolates obtained respectively. The reason why the two ready prepared media failed to catch up all dermatophyte isolates may be due to, the media subjected to dryness before the growth of slow growing dermatophytes as T.violaceum and T.verrucosum and plates of Derm-Deut subjected rapidly for contamination by non dermatophyte moulds. These results coincide with (28) who obtained high rate of dermatophytes on Dermasel agar and with (31) who found that the usefulness such in-office culture systems is still a matter of debate.

Phenotypic identification of dermatophyte species rely on macromorphology of colonies (rate of growth, texture and colour of surface and reverse side), and micro-morphology (presence and characters of macroconidia and microconidia as well as modification of hyphae e.g. spirals, nodular organs, favic chandeliers and pectinate bodies) and when identification of them not reached, biochemical tests such as urease, nutritional requirements and in-vitro hair penetration test will help in its identification $(32,33)$.

On the other hand, besides rice grain medium which used for differentiation of M.canis from M.audouini (18), bromocrusol purple medium (34) for differentiation of T.mentagrophytes from T.rubrum, other differential media were propagated $(16,17,35,36)$ for differentiation between dermatophytes confused in their morphological and physiological characters.

In the present work 62 dermatophyte isolates obtained from human and animals dermatophytosis as well as from soil were subjected for macro-morphology, micromorphology examination and culture on four differential media (RG, LA, BCP and MHB).

The identification of 48 isolates obtained from human cases revealed 15 isolates of M.canis, 12 of T.violaceum, 12 of T.rubrum, 5 of E.fluccosum and 4 of T.mentagrophytes. These results are in accordance with those published $(17,36)$ who found that M.canis was 
the predominant dermatophyte isolated in last few years in Egypt followed by T.violaceum and T.rubrum, while differ from (38) who isolated T.violaceumin $67 \%$ from cases of tinea capitis in Sharkia Governorate which may be due to the variation of results according to the place where the study were done.

Concerning with identification of dermatophytes isolated from animals, it was found that while T.verrucosum was the only dermatophyte isolated from cases of cattle, M.canis was the only dermatophyte isolated from dogs and cats. Similar results were recorded $(39,40)$ who pointed out that T.verrucosun is the major dermatophyte encountered in cattle and with $(41,42)$ who considered M.canis as the dominant species in dogs and cats.

The two dermatophyte isolates obtained from 5 soil samples were identified as $M$. gypseum, the result which is in agreement with (43).

The conventional (phenotypic) method for identification of dermatophytes in the current study were succeed to identify all isolates through macro-morphology and micro-morphology into species which confirmed by the four differential media used

Nucleic acid based technique relies on the genotypic differences in pathogenic organisms. They are intrinsically more specific and more precise than those based on phenotypic features (44).

Recently a number of methods have been reported for molecular identification of dermatophytes which include:

1-Polymerase chain reaction targeting $18 \mathrm{~s}$ Rdn (45).

2-Random amplified polymorphic DNA [RABD] (46).

3-PCR using single simple repetitive oligonucleotide (GACA)4 (7)

4-Restriction fragment length polymorphism [RFLP] (47).
5- Chitin synthesis I (CHSI) gene sequencing (15).

\section{6- Arbitrary primed PCR [AP-PCR] (7).}

On the otherhand, PCR immunosorbant assay[PCR-ELISA], line block PCR[PCRRLP] and multiplex real time PCR are propagated for detection of dermatophytes in clinical materials $(48,49,50)$.

In the present study three methods were used for molecular identification of dermatophytes which include;

a) PCR for amplification of ITS1 and ITS4 followed by restriction fragment length polymorphism (RFLP) using MvaI for 30 isolates of dermatophyte formely identified by phenotypic method.

b) Application of PCR using single repetitive oligonucleatede (GACA) 4 for35 dermatophyte isolates identified by phenotypic and RFLP methods.

c) DNA sequencing which done only for 5 representative isolates.

Amplified products using universal primers ITS1and ITS4 from T.violaceum, T.rubrum, T.mentagrophytes and E.fluccosum were found at 690 bp while M.canis was at $740 \mathrm{bp}$, the result which identical (11).

MvaI digestion of amplified products in the first step revealed unique restriction pattern. Analysis of number and size of patterns identified the 35 isolates examined of dermatophytes into species typical to those with phenotypic method. The results of current work by RFLP are coinciding with (51) who found that PCR-RFLP of ITS region was easily identifiable fragment patterns for all dermatophyte isolates into species.

Concerning with (GACA) 4 -based PCR in the current study, it was found that all isolates were identified by it into identical manner as phenotypic as well as PCR-RFLP methods. The present study is in agreement with those done by $(7,52)$ when they found that repetitive primer (GACA)4 was able to amplify all dermatophytes into species. Comparing the two methods the RFLP is 
complex, needing much effort and time while (GACA) 4 method is simple and rapid.

While the two methods of genotypic in the present study are in agreement in $100 \%$ with the results of phenotypic methods. Identification of dermatophyte by the APCPCR was in agreement with the phenotypic methods in $86.8 \%$ of the isolates. It may be due to shortage in phenotypic identification as lack experience in identification of dermatophytes and use of macro-morphology and micro-morphology without help of other methods as differential media (28).

On the other hand five dermatophyte isolates [M.canis (1), T.violaceum (1), T.verrucosum (1) and T.rubrum (2)] formerly identified by RFLP and repetitive primer (GACA)4 were sent to sequencing then the data were analyzed by DNA software comparing to those in Gen Bank. While M.canis, T.verrucosum, $T$. violaceum and one isolate of T.rubrum were found to be identical to similar in Gen Bank, the other isolate of T.rubrum obtained from a case of human tinea corporis was found to be identical (99\%) for the sequence of the T.raubitscheki, a dermatphytes considered as atypical dermatophyte confused of T.rubrum and rarely isolated from people who live or traveled in Mediterranean $(53,54)$. While it differ from T.rubrum in some morphological and physiological characters specially urease test which is positive in 3 days, T.raubitschekii is homologue genetically with T.rubrum (55). It is the reason why RAPD and (GACA)4 not differentiate them in the present work.

Although sequencing provides a very accurate and useful method for the identification of dermatophytes, it is highly expensive to use in routine genotypic identification the reason why (56) recommended its use for identify a minority of atypical isolates of dermatophytes.

The results in the current study revealed the capacity of phenotypic (morphological and differential media) and genotypic (RFLP) and repetitive primer) in equally manner to identify the isolates of dermatophytes obtained from human, animals and soil. Although molecular methods is rapid and represents technological advance in laboratory diagnosis, it is expensive and facing some problems in our country. So we recommended its use in identification of dermatophytes for atypical and variant of species.

\section{REFERENCES}

1.Weitzman I and Summerbell RC (1995): The Dermatophytes. Clin.Microbiol. Rev., 8: 240-259.

2.Emmons CW (1934): Dermatophytes natural grouping based on the form of the spores and accessory organs. Arch. Dermatol. Syph., 30: 337

3.Matsumoto $T$ and Ajello L (1987): Current Taxonomic Concepts Pertaining to the Dermatophytes and Related Fungi. International J. Dermatol., 26 (8): 491-499.

4.White TC, Oliver BG, Graser Y and Henn MR (2008): Generating and testing molecular hypothesis in the dermatophytes. Eukaryotic.Cell., 7: 1238-1245.

5.Wagner DK and Sohnle PG (1995): Cutaneous defenses against dermatophytes and yeasts. Clin.Microbiol. Rev., 8 (3): 317-335.

6.Spiewak $R$ and Szostak W (2000): Zoophilic and geophilic dermatophytoses among farmers and non farmers in eastern Poland. Ann. Agric. Environ. Med., 7:125-129.

7.Faggi E, Pini G, Campisi E, Bertellini C, Difonzo $E$ and Mancianti $F$ (2001): Application of PCR to distinguish common species of dermatophytes.J. Clin. Microbiol., 39 (9):3382-3385.

8.Monod $M$, Jaccound S, Stirnimann $R$, Anex $R$, Villa $F$, Balmer $S$ and Panizzon $R G$ (2000): Economical microscopic configuration foe direct mycological 
examiantrion with fluorescence in dermatology. Dermatol., 201: 246-248.

9.Gräser Y, Kuijpers AF, Pesber $W$ and de Hoog GS (2000): Molecular taxonomy of Trichophyton rubrum complex. J. Clin. Microbiol., 38: 3329-3336.

10.Hsiao CR, Hirang L, Bouchara JP, Barton RH and Cachang TC (2005): Identification of Medically important molds by an oligonucleotide array. J. Clin. Microbiol., 43: 3760-3768.

11. Shehata AS, Mukherjee PK, Aboulatta HN, El-Akhras AI, Abbadi SH and Ghannoum MA (2008): Single-step PCR using (GACA)4 primer: utility for rapid identification of dermatophyte species and strains.J. Clin. Microbiol., 46 (8): 26412645.

12.Gutzmer R, Mommert S, Kuttler U, Werfel $T$ and Kapp $A$ (2004): Rapid identification and differentiation of fungal DNA in dermatological specimens by light cycler PCR. J. Clin. Microbiol., 53: 1207-1214.

13.Faggi E, Pini $G$ and Campisi $E$ (2002): PCR finger printing for identification of common species of dermatophytes. J. Clin. Microbial., 40: 4804-4805.

14.Rakcman J, Bui U, Iafe $K$, Chen YC, Honeyeulti $R$ and Cookson BT (2005): Multi locus DNA sequence comparisons rapidly identify pathogenic molds. J. Clin. Microbiol., 43: 3324-3333.

15.Rebell $G$ and Taplin $D$ (1974): Dermatophytes. Their Recognition and Identification. U. Miami Press, Coral Gables, Fl. Fine color photographs

16.Frey $D$, Old-field $R J$ and Bridger RCA (1976): Colour Atlas of Pathogenic Fungi; London: Wolfe Medical Publications Ltd.

17.Kane J Summerbell RC, Sigler L, Krajden $S$ and Goeffrey $L$ (1997): Laboratory Handbook of dermatophytes. Star publishing. Belmont, CA., USA.

18.Larone DH (2002):Medically Important Fungi: A Guide to Identification. $4^{\text {th }}$ ed.
Washington, D.C.: American Society for Microbiology Press.

19.Taha $M$ (2011): Medical Mycology:Atlas of Medical Important Fungi and Dermatomycosis. Dermatophytes (P 74102) and Dermatophytosis (P.238-252) Mecca Printing House Cairo Egypt.

20.Gräser Y, El Fari M, Preshber W, Sterry $W$ and Tietz HJ (1998): Identification of common dermatophytes (Trichophyton, Microsporum, Epidermophyton using polymerase chain reaction. Br. J. Dermatol., 138: 576-582.

21.AboulMagd $M$ and Taha $M$ (2001): Rice Lactitmel Agar: A new modification of Borelli's Medium for identification of dermatophytes. Egypt. J. Med. Microbiol., 10: 595-605.

22.Tahaa $M$, El Fangaryb $M$ and Saudyb $W$ (2013): MHB: a new medium for isolation and identification of dermatophytes. Egyptian Women's Dermatologic Society, 10 (Issue 3): 172-176.

23.Fischer $F$ and Coak $N$ (1998): Fundamentals of Diagnostic Mycology. W.B. Saunders Company.

24.Vanbreuseghem $R$ (1952): Technique biologique pour isolement des dermatophytes du sol. Annual of Society of Belgique Medicine, 10: 165-171.

25.Liu D, Coloe S, Baird $R$ and Pedersen $J$ (2000): Application of PCR to the identification of dermatophyte fungi.J. Med.Microbiol., 49 (6):493-7.

26.Kanbe T, Suzuki Y, Kamiya A, Mochizuki $T$, Kawasaki M, Fujihiro $M$ and Kikuchi A(2003): Species identification of dermatophytes: Trichophyton, Microsporum and Epidermophyton by PCR and PCR RFLP targeting of the DNA topoisomeres II genes. J. Dermatol. Sc., 33: 41-54.

27.Girgis SA, El-Fakkar NMZ, Badr $H$, Shaker OA, Metwally $\mathrm{FE}$ and Bassim $\mathrm{HH}$ (2006): Genotypic identification and antifungal susceptibility pattern of 
dermatophytes isolated from clinical specimens of dermatophytosis in Egyptian patients. Egyptian Dermatology Online Journal, 2 (2): 1-23.

28.Kannan $P$, Janake $C$ and Selva GS (2009): Prevalence of dermatophytes and other fungal agent isolated from clinical samples. Indian J. of Med. Microbiol., 24 (3): 212-215.

29.Levitt JO, LevittBH, Akhavan $A$ and Yanofsky $H$ (2010): The Sensitivity and Specificity of Potassium Hydroxide Smear and Fungal Culture Relative to Clinical Assessment in the Evaluation of Tinea Pedis: A Pooled Analysis Dermatology Research and Practice, pp. 8.

30.Robert $R$ and Pihet $M$ (2008): Conventional methods for diagnosis of dermatophytosis. Mycopathologia,166(56):295-306.

31.Shadomy HJ and Philpot CM (1980): Utilization of standard laboratory methods in the laboratory: diagnosis of problem dermatophytes. Am. J. Clin.Pathol., 74:197201.

32.Padhye AA and Summerbel RC (2010): The dermatophytes. In: Toply and Wilson's. Microbiology and Microbial Infection. Medical Mycology.Tenth Ed. Hodder Arnold-ASM.P220-243.

33.Fisher $J B$ and Kane $J$ (1971): The detection of contamination of Trichophyton rubrum and Trichophyton mentagrophytes . Mycopathologia, 43: 170-180

34.Salkin IF, Padhye AA and Kemna ME (1997): A new medium for the presumptive identification of dermatophytes. Clin. Microbiol., 35 (10): 2660-2662.

35.Gromdski S, Ramani $R$ and Chaturvedi $V$ (2003): Evaluation of new medium for identification of dermatophytes and primary dimorphic pathogens. J. Clin. Microbiol, 41:467-468.

36.Abou El Enin A, Khedr $M$ and Abou El Ata A (2007): Tinea capitis in Assiut Governorate (A clinical and mycological study). Egypt J. of Hospital Med., $29: 738=744$

37.Farouk A (2013): Phenotypic and Genotypic identification of T. Violecium. Ph.D, Thesis (Dermatology Department), Faculty of Medicine, Zagazig University.

38.Khosravi AR, Shaki H, Taghapour T, Yahyaraeyat $R$ and Ghayasi $M$ (2008): Presentation of dermatophyte lesion on different sites of adult cattle. J.Vet.Res., 63: 37-39

39.Yahyaraeyat $R$ (2009): Occurrence of Animal Dermatophytosis in Tehran-Iran. World Journal of Zoology,4(3): 200-204

40.Nweze EI (2011): Dermatophytoses in domesticated animals. Rev. Inst. Med. Trop. Sao. Paulo., 53 (2):94-99.

41.Ahmed AA (2013): Studies on Microsporum canis isolated from human and animals. M. Vet. Thesis (Mycology) Zagazig University.

42.Osman MM (2012): Isolation and Identification of Geophilic Dermatophytes in Sharkia Governorate. Master Vet. Thesis (Mycology). Zagazig University

43.Michell TG, Sandin RL, Bowman BH, Meyer $W$ and Merz WG (1994): MolecualrMycologyL DNA probes and applications of PCR technology. J. Med. Vet. Mycol., 32: 351-366.

44.Dubach MM, Lacroix C, de Chauvin MF, Le Gall I, Giudicelli C, Lorenzo $F$ and Derouin $\quad F \quad$ (2001): $\quad$ Rapid discrimination among dermatophytes, Scytalidium spp., and other fungi with a PCR-restriction fragment length polymorphism ribotyping method. J. Clin. Microbiol., 39 (2): 685-690.

45.Zhang Z, Li D and Wange W (1997): Typing of common dermatophyte by random application

46.Jackson CJ Barton RC and Evans EG (1999): Species identification and strain differentiation of dermatophyte fungi by $\mathrm{J}$. Clin. Microbiol., 37: 931-936. 
47.Kane $R$, Nakamura $Y$, Watanaba $S$, Takahash Tsujimto $H$ and Hasegawa $A$ (1998): Molecular analysis of chitin synthase 1 (CHS1) gene sequences of Trichophyton mentagrophytes complex and T. rubrum. Curr. Microbiol., 37: 236-239.

48.Arabatzis M, Bruijnesteijn van Coppenraet LE, Kuijper EJ, de Hoog GS, Lavrijsen AP, Templeton $K$, van der Raaij-Helmer EM, Velegraki A, Gräser Y and Summerbell RC (2007): Diagnosis of common dermatophyte infections by a novel multiplex real-time polymerase chain reaction detection/identification scheme. Br. J. Dermatol., 157 (4): 681-689.

49.Bergmans AM, van der Ent M, Klaassen A, Böhm N, Andriesse GI and Wintermans $R G$ (2010): Evaluation of a single-tube real-time PCR for detection and identification of 11 dermatophyte species in clinical material. Clin. Microbiol.Infect., 16 (6): 704-710.

50.Beifuss B, Bezold G, Gottlöber P, Borelli $C$, Wagener J, Schaller $M$ and Korting $H C$ (2011): Direct detection of five common dermatophyte species in clinical samples using a rapid and sensitive 24-h PCRELISA technique open to protocol transfer. Mycoses, 54 (2): 137-145.

51.Jackson CJ, Barton RC, Kelly SL, Evans $E G V$ (2000): Strain identification of
Trichophyton rubrum by specific amplification of subrepeat elements in the ribosomal DNA nontranscribed pacer. J. Clin. Microbiol., 38:4527-4534.

52.Roque H, Vierna R, Rato $S$ and LuizMartis (2006): Specific primer (GACA)4 for rapid detection of Microsporiumaudounii by PCR in clinical samples. J. Clin. Microbiol., 44 (12):43364341.

53.Kane J, Krajden S, Summerbell RC and Sibbald $R G$ (1990): Infections caused by Trichophyton raubitschekii: clinical and epidemiological features. Mycosis, 33: 499506.

54.El Ghandour T, Khafagy $N$, Khafagy $A$ and Taha $M$ (2001): A study of two atypical dermatophytes:T.prolefrans and T.raubitrscheki) and one dermatophytoids (T.fisheri )for the first time in Egypt. Egypt. J.of Med. Microbiol., 10:393-395

55.Tietz HJ, Hopp $M$ and Gräser $Y$ (2002): First isolation of Trichophyton raubitschekii (syn. T. rubrum) in Europe. Mycoses, 45 (1-2): 10-14.

56.Li HC, Bouchara JP, Hsu MML, Barton $R, \quad S u \quad S$ and Chang TC (2008): Identification of dermatophytes by sequence analysis of the rRNA gene internal transcribed spacer regions. Journal of Medical Microbiology, 57: 592-600. 
الملخص العربه

دراسات مقارنة بين طرق الاطر المظهرية والاطر الوراثية لتثخيص مرض الفطريات الجلدية للانسان والحيوان

\author{
محمد طة محمود** ، صبرى إسماعيل عيسى ***، احمد إسماعيل احمد يونس** \\ قسم البكتريولوجى و الفطريات و المناعة ـ كلية الطب البيطرى - جامعة الزقازيق*معهد بحوث صحة \\ الحيوان بالدقى *
}

في الدر اسة الحالبة تم تجميع عدد با عينة من الفطريات ـ تم الحصول عليها من الالتهابات الجلدية

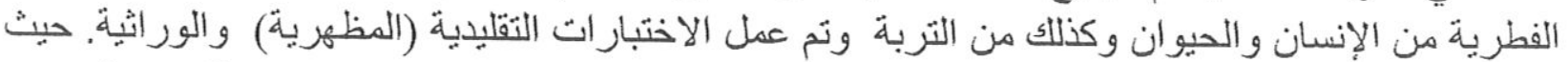

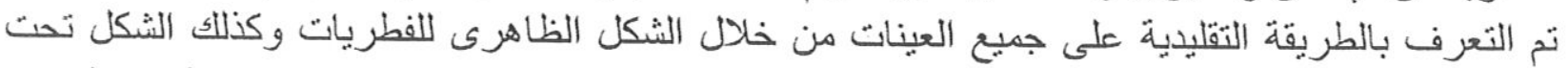

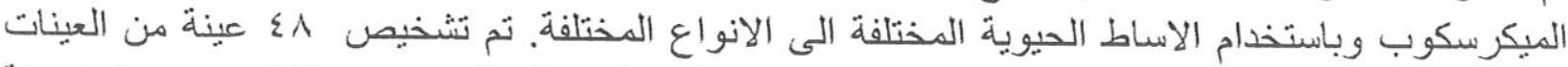

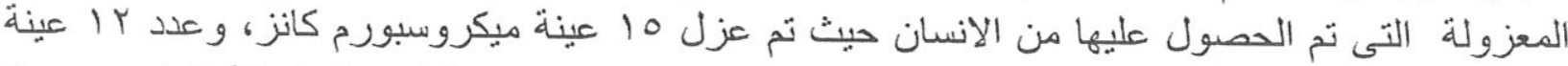

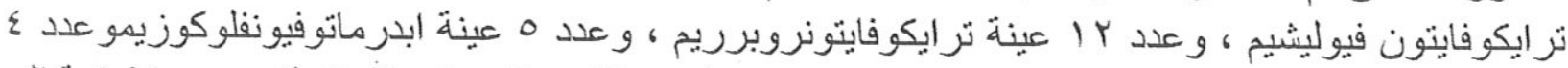

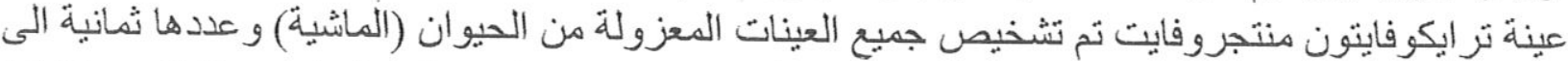
تز ايكوفايتون فريكوزيم ، في حين تم نشخيص أربع عينات نم الحصول علئها من الكلاب والقطط مبكروسبورم كانز ومن ناحية أخرى تم تشخيص العينات المعزورلة من التربة مبكروسبور مجيبسيخ ومن الجهة الاخرى استخدمت ثلاث طرق الجينية (الور اثبة) لدر اسة عدد ، ب من العينات المعزولة و التي تم تحديدها سابقا بالطريقة التقليدية (الطريقة المظهرية) والتى تشمل:

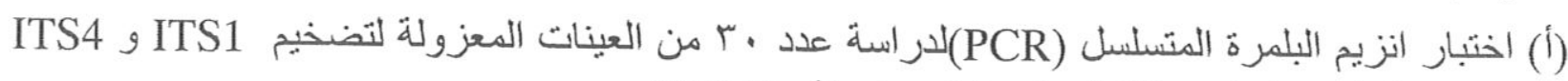

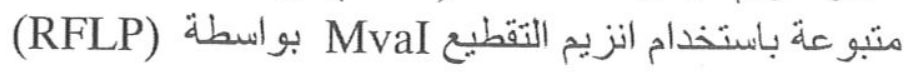

(ب) إختبار انزيم البلمرة المتسلسل لدر اسة عدد • ب من العينات المعزولثباستخدام بر ايمر 4 (GACA) وتم در استها ايضا باستخدام (RFLP)

(ج) اختبار تسلسل الحمض النووي الذي تم لعدد عبنات وهى ميكروسبورم كانز ، تز ايكوفايتونفريكوزيم ،

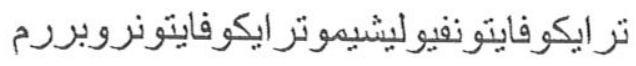

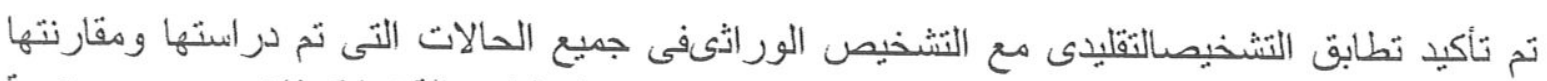
باستخدام (RFLP) مع انزيم التقطيع MvaI وكذلك 4 (GACA). باستثناء حالة تر ايكوفاينون روبررم نسبة

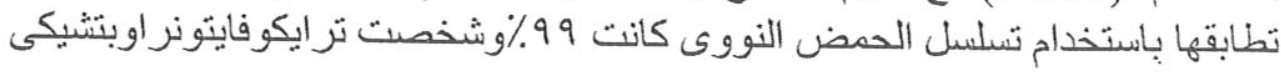

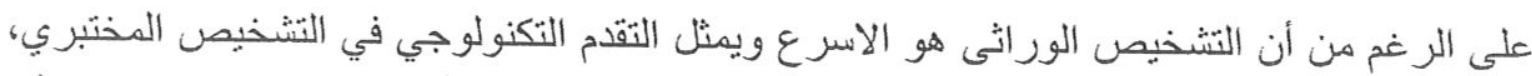

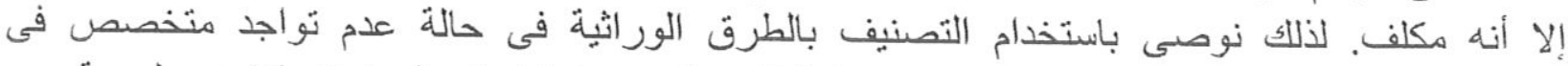
تصنيفالفطريات الجلدية او وجود عز لات غير نمطية لا يسهل تصنيفها او فى الدراسات الابيدميولوجية. 